\title{
Review
}

\section{Education and science museums. Reflections in Italy and on Italy}

\section{Paola Rodari}

The educational function of science museums was born with the first naturalistic collections ever, flourished in $16^{\text {th }}$-century Italy in its Renaissance period with purposes including research, promotion of science (then the newly-born natural sciences), education (then exclusively reserved to university students), but also, in more general terms, the spiritual elevation of noblemen and prelates (the education of noblewomen had to wait at least another century). ${ }^{1}$

This dual function (direct support to the educational system and the education of non-experts - today it would be termed life-long education) has continued to exist up to this point in time, the early $21^{\text {st }}$ century, although with different interpretations, methods and degrees over the centuries. The pedagogic thought and the educational experimentations carried out in approximately five century of history have allowed the educational mission of museums to acquire many different facets, drawing a task having an increasingly higher and complex social value.

In order to better understand this concept, it will be useful to consider the stance recently expressed by the international community of science museums. Four hundred science centres and museums around the world met in Toronto for the Fifth Science Centre World Congress $\left(15^{\text {th }}\right.$ to $20^{\text {th }}$ June 2008) and signed a declaration of social responsibility whose foundation is the commitment to education: promotion of engagement in research, spreading of a scientific culture, fostering the skills to produce innovation through problem-solving and creativity, educating children to become "agents of change" in view of the UNESCO goals for a sustainable development, and finally engaging citizens in the debate and in the governance of science and technology. ${ }^{2}$

Maybe they are too conceited? Analyzing in detail the activities of the most important science museums around the world (the National History Museum and the Science Museum of London, the Exploratorium of San Francisco, the Cité des Sciences et de l'Industrie of Parigi, the Ontario Science Centre of Toronto, only to mention my favourite ones) one cannot but be impressed by the potential for a cultural and social impact of these institutions. Certainly this does not apply to the whole of the science museums around the world, but the trend really is encouraging: new facilities are created, the historical ones are strengthened, they boost their prestige, enlarge their scope of action, increase their budget (which is never enough though). ${ }^{3}$

In Italy the same situation occurs. Also in our country science museums are a well-established reference for schools and lively and original cultural agencies. Not only owing to the birth in the eighties of the first science centres and interactive museums (pioneers were Città della Scienza of Naples and the Immaginario Scientifico of Trieste ${ }^{4}$ ), not only owing to the renewal and the boost in the supply of the most important conservative museums (such as the Museo Nazionale della Scienza e della Tecnologia "Leonardo da Vinci" of Milan and the Museo Tridentino di Storia Naturale di Trento), but also for the widespread presence across the national territory of hundreds of institutions of any size and type: museums of natural science, history of science, aquariums, planetariums, botanic gardens, but also ecomuseums, demo-ethno-anthropological museums, visitor centres of national parks and, a phenomenon of the past few years, university collections which everywhere in Italy are restructuring themselves in university museum systems. ${ }^{5}$

Probably too slowly - certainly more slowly than their British and French counterparts (but also the Spanish and Portuguese ones) - the Italian science museums are growing, in the first place widening the range of their educational activities, offering beside guided tours and conferences (the two typical offers) also hands-on educational workshops, demonstrations to the public, science shows, events for families and finally debates and scientific cafés. 
The educational role played by science museums was highlighted also in the report (dated May 2007) by the Inter-ministerial Committee for the Development of the Scientific and Technological Culture chaired by Luigi Berlinguer, which presents an overall assessment of the state of the scientific culture in Italy and a series of operational guidelines for its enhancement, including the improvement of the didactic collaboration between schools and museums. ${ }^{6}$

However, there is a fact that we want to highlight the most and it is the quantitative and qualitative growth of the Italian literature specialised in museum education and communication. Not that fundamental contributions did not exist in the past, but the Italian environment, once very distant and lacking a mutual communication, characterised by some excellence peaks but also by a large void, has slowly become a community of operators in the sector full of reflections, experiences and exchanges.

This very journal has published in the past four years approximately thirty articles on museums and science centres, and about half of them were by authors working in Italy and addressing the educational role played by museums. ${ }^{7}$ This theme has been given an increasingly large space also in the programme of the national meeting of Forlì, now in its seventh year, whose proceedings are subsequently published. It is an annual meeting on science communication which has gradually become the meeting point of once separate communities (of journalists, museum operators from different institutions and experiences, scientists, social researchers, historians, etc.) which are now starting to debate with positive results. ${ }^{8}$

A very important role in the reinforcement of this dawning extensive community of science communicators in museums will be certainly played by the journal edited by ANMS (Associazione Nazionale Musei Scientifici - National Association of Science Museums), Museologia Scientifica, which in 2007 underwent a graphic restyling, also adopting a new approach. It is no longer focused on the traditional themes of the preservation and the journal now acts as a platform for a debate on the new methods of public science communication, on the role the scientific museums should play in the dialogue between science and society and the need for new vocational training when addressing these challenges.

The year 2007 also saw the publication of two manuals on museology (a wide-ranging book and a scientific one). Although not dealing exclusively with museum education, the two books have focussed chapters that present extensive references to international literature and practices. ${ }^{9}$ Following is a quotation from Lucia Cataldo and Marta Paraventi, authors of Il museo oggi. Linee guida per una museologia contemporanea (Museums today. Guidelines for a contemporary museology). Their introduction to the chapter devoted to museum communication reads: "Acknowledging the social and cultural relevance of museums means also to better understand the importance of their role as educational institutions. Acknowledging the social and cultural relevance of museums means to pave the way to the identification of strategies guaranteeing the implementation of the "study, education and entertainment" goals defined by ICOM (International Councils of Museums, established under the aegis of UNESCO, editor's note)". According to the authors, in our country the widespread presence of a huge cultural heritage has probably forced us to focus our attention mostly on preservation issues, rather than on communication and education; but now it is time to address this task and to learn from international experiences. Putting the visitor at the centre of the museum experience is also the central goal of new museology (which obviously does not implies disregarding research and preservation tasks), the two books totally agree on this point: "The new awareness on the central role of the visitor does not stem from a political or ethical revaluation of their capabilities or rights (although this is certainly converging), but from the observation (based on research) that between the intention of the curator (but also of the promoters of public events and debates) and what really occurs in the public there can be a wide gap. (...) Hence, in order to dialogue, or even to negotiate or to participate: apparently the latest mission of science museums is precisely to study, to design and to implement a museum that communicates by dialoguing and receiving the participation of its public, in contrast to a museum that talks to itself and is insensitive to the feelings of visitors". ${ }^{10}$

This new type of science museum, able to fully address contemporary challenges, as it is able to put everything around the visitor, is also the subject of a book published less recently, yet still worth to be mentioned in this review. Luigi Amodio, Annalisa Buffardi and Lello Savonardo are the editors of $L a$ cultura interattiva. Comunicazione scientifica, musei, science center (Interactive culture. Science communication, museums, science centres), "which presents an analysis of the transition from a traditional museum to the new science-centre concept", whose identikit is provided here before 
focussing on "the new forms of science communication, which imply an increasing quantity of interactive and performing displays and, therefore, the active participation of the users". ${ }^{11}$

Three very recent books take another view and focus totally on informal education.

Elisabetta Falchetti is the author of the first volume from the series Memorie di Museologia Scientifica (Memoirs of Science Museology), entitled Costruire il pensiero scientifico in museo. Spunti e riflessioni sull'educazione scientifica nei musei delle scienze (Building scientific thinking in a museum. Insights and reflections on science education in science museums). ${ }^{12}$ The first section of the book is devoted to the discussion on the deep sense of the educational role by museums, finding its bases also in a definition of scientific thinking, and therefore of what a "better" (more faithful) science communication can be. To this purpose, the author explores the Italian and international literature, but also interviews a number of experts, with a full report included in the text: Carlo Bernardini, Silvia Caravita, Alessandra Guidotti, Claudio Longo, Lorenza Merzagora, Vincenzo Padiglione, Alessandra Sperduti and Adriana Valente. The second part of the book is devoted to understanding needs and attitudes of the public of science museums, especially through the case study of the Zoology Museum of Rome, Falchetti being its curator. The third part offers some examples (still in Rome) of good educational practices. An effective museum education, according to the author, should be able to interpret contemporary issues not only in terms of sustainable development, but also of multi-culture, democratisation, "human ethics" in compliance with the educational guidelines put forward by Morin for UNESCO: " ${ }^{13}$ "Science museums (and any other museum) cannot be strangers to the educational needs of our times: they should be actively involved in the change and in the search for solutions to contemporary problems. However, up to now, only a little part of the debate has apparently entered our museums (although in terms of Sustainable Development). (...) New educational goals for a new culture of sustainability require deep changes and should involve not only contents, but also contexts, languages, methods of expression, activities, relations with visitors: the entire strategy, management and museum life. This can stem only from a higher participation of the museum operators in the whole range of prospects and issues of sustainability and not only those of scientific research".

The second book, Conoscere il suono, la Natura, l'Universo. Comunicare, apprendere e valutare in ambito non formale (To know sound, nature, the universe. To communicate, to learn and to evaluate in a non-formal context) edited by Mario Campanino, aims at highlighting the relations between formal and informal education, schools and museums. ${ }^{14}$ The book stems from the experience of the Foundation IDIS-Città della Scienza of Naples, and in particular from the PENCIL project (Permanent European Resource Centre for Informal Learning), which for three years, aside from the Naples museum, has seen the participation of many other European museums and science centres. ${ }^{15}$ Also this book presents a number of case studies, whereas some contributions offer more general food for thought: on the evaluation of the effectiveness of the interventions, the evaluation of students in non-formal contexts, on the possible alternative communication/education tools such as drama performances. An aspect we deem particularly interesting is the stress on the need to create deeper and less casual relations with schools, to produce more long-term projects and, above all, to involve teachers more actively. On the one hand, as Silvano Tagliagambe wrote in the introduction, school autonomy allows schools (and especially school networks) to become protagonists in the activities outside school hours, able to promote them and guide them according to specific needs; on the other hand, museums can only gain from the didactic skills and the creativity of their teachers. A better collaboration between schools and museums may also avoid, according Marco Serpico, a certain degree of educational schizophrenia whose victims are always the students: "I have already dealt with the unquestionable enrichment that informal didactic activities can contribute to the scientific education of students. Too often does this enrichment translate into a simple juxtaposition procedure of different learning methods. So, when I speak about best practices within PENCIL, it is about best practices in building bridges to facilitate communication and integration between two worlds frequently all too distant." The risk students run of being subject to schizophrenic didactics, as well as the risk teachers run of being confined at the borders of the informal education experience are completely avoided in the case of Scienza Under 18, a completely internal school project self-managed by teachers, although using the instruments of informal communication in the framework of the largest science museum in Italy, the Museo Nazionale della Scienza e della Tecnologia "Leonardo da Vinci" of Milano. Scienza Under 18 is an event where school students present to peers their scientific projects, in a sort of festival-exhibition. The event, originally held only in the large courtyard of the 
museum, has now spread across Lombardy and part of Liguria. ${ }^{16}$ Scienza Under 18 has recently turned 10 years old and this anniversary was celebrated by a book telling its history, but above all reflecting on the different aspects of its experience: from peer-to-peer education to the involvement of families, from the research on the perception of science by students to the didactic use of instruments taken from scientific journalism. ${ }^{17}$

The final book in this review regards the field where Italy is probably experiencing a delay in contrast to other European countries (especially Great Britain): studies on visitors (aiming at understanding what the significant variables in the museum experience are) and evaluation (i.e. the set of practices and methods used to verify the communication and educational effectiveness of specific permanent or temporary exhibitions or activity programmes). The book, featuring contributions in English, Italian and French, is edited by Emma Nardi, a full professor of Experimental Pedagogy at the University of Roma Tre, and is totally devoted to this field of research/action. Although it is definitely more oriented towards non-science museums, the volume can be of interest also for scientific museology, presenting innovative and original experiences, including programmes devised for publics harder to please, such as teenagers and disabled people. ${ }^{18}$

An overview of all these releases allows us to reach the conclusion that the Italian community of science museums is gradually becoming a widespread network, moving away from the old situation of a mere set of distant excellence centres. It is increasingly opening to the outside, debate is launched internally, practices and reflections are now being exchanged. Perhaps the number of exchanges does not suffice yet; for example, there are still too few cross-references in the texts, although individually they are extremely interesting and this appears to be a clear signal that the dialogue among different institutions is still isolated.

Incidentally, it is to be noted that Italian contributions are almost totally missing from international magazines in this field, such as Curator and Museum Management and Curatorship, where AngloSaxons do prevail.

These are all good reasons to continue to rely on, or better still, to rely more on JCOM, which has the advantage to be an Italian journal, but at the same time it has a wide international scope (the names of the members of the new Editorial Board really are impressive) and is able to connect all the different facets of science communication.

Translated by Massimo Caregnato

\section{Notes and references}

\footnotetext{
${ }^{1}$ On this aspect of Renaissance which unfortunately is still unknown to non-experts see also: Giuseppe Olmi, L'inventario del mondo. Catalogazione della natura e luoghi del sapere nella prima età moderna, Bologna 1992; Paula Findlen, Possessing Nature: Museums, Collecting, and Scientific Culture in Early Modern Italy, University of California Press, Berkley 1994 ${ }^{2} \mathrm{http} / / / \mathrm{www} .5 \mathrm{scwc}$.org/TheTorontoDeclaration/tabid/133/Default.aspx.

${ }^{3}$ For an overview of the history but also of the present times of science museums around the world see also: Matteo Merzagora e Paola Rodari, La scienza in mostra. Musei, science centre e comunicazione, Bruno Mondadori Milano 2007.

${ }^{4}$ On the history of the Città della Scienza of Naples, representing a very innovative model of science centre on the international stage, see also: Pietro Greco, La città della scienza. Storia di un sogno a Bagnoli, Bollati Boringhieri, 2006.

${ }^{5}$ On the rising of science centres in Italy see also: Paola Rodari, Birth of a science centre. Italian phenomenology, Jcom 5(2) 2006; following are statistical studies on the Italian science museums: Emanuela Reale, I musei scientifici in Italia, Franco Angeli, Milano 2002 e Emanuela Reale, I musei scientifici in Italia: la ricerca, la didattica e la diffusione della cultura scientifica, Museologia scientifica, Vol. 22, No. 1 2006; there are also two tourism-related guides: Monza, Francesca Barbagli, Fausto, La scienza nei musei, guida alla scoperta dello straordinario patrimonio museale scientifico italiano, Orme editori, 2006 and Massimo Bozzo, I luoghi della scienza, guida ai musei e alle raccolte scientifiche italiane, Di Rienzo editore, 2005.

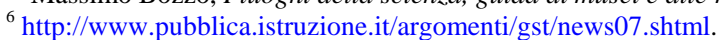

${ }^{7}$ Following are the fifteen articles dealing especially with the educational aspects of the mission of science museums: Leonardo Alfonsi, Literature review, Jcom 4(4) 2005; Sara Calcagnini, Debating as an educational method to science and citizenship, Jcom 6(3) 2007; Sara Calcagnini, SMEC project: an European dimension for the relation between museum and school, Jcom 3(3) 2004; Monia Cardella, Science is not for me. Visitors' attitudes to learning in an Italian science centre, Jcom 5(2) 2006; Francesca Conti, The public's rapport with hands-on activities. An evaluation of "Explore-At-Bristol", Jcom 3(2) 2004; Alessandra Drioli, Contemporary aesthetic forms and scientific museology, Jcom 5(1) 2006; Stefano Giovanardi, Apriti Cielo: the public's astronomical imagery as a key to evaluate a museum project, Jcom 5(4) 2006; Michele Lanzinger, The science and
} 
society movement and the MUSE project, Jcom 6(2) 2007; Matteo Merzagora and Paola Rodari, The Lisbon post-its: how science-in-society issues were reflected in the last ECSITE meetings, Jcom 6(2) 2007; Paola Rodari, The role of science centres and museums in the dialogue between science and society, 6(2) 2007; Paola Rodari, Birth of a science centre. Italian phenomenology, Jcom 5(2) 2006; Paola Rodari, Beautiful guides. The value of explainers in science communication, Jcom 4(4) 2005; Paola Rodari, Learning in a museum. Building knowledge as a social activity, Jcom 4(3) 2005; Paola Rodari, A place to discover - teaching science and technology with museums of Maria Xanthoudaki (ed), Jcom 2(4) 2004; Maria Xanthoudaki, Museums for Science Education: can we make the difference? The case of the EST project, Jcom 6(2) 2007.

${ }^{8}$ http://ics.sissa.it/index.php?pg=7.

${ }^{9}$ Lucia Cataldo Lucia e Marta Paraventi, Il museo oggi. Linee guida per una museologia contemporanea, Hoepli, Milano, 2007; Matteo Merzagora e Paola Rodari, La scienza in mostra. Musei, science centre e comunicazione, Bruno Mondadori Milano 2007.

${ }^{10}$ Matteo Merzagora e Paola Rodari, La scienza in mostra. Musei, science centre e comunicazione, Bruno Mondadori Milano 2007.

${ }^{11}$ Luigi Amodio, Annalisa Buffardi, Lello Savonardo, La cultura interattiva. Comunicazione scientifica, musei, science centre, Edizioni Oxiana, Napoli 2005.

${ }^{12}$ Elisabetta Falchetti, 'Costruire il pensiero scientifico in musei. Spunti e riflessioni sull'educazione scientifica nei musei delle scienze', Memorie di Museologia scientifica, No. 1 dicembre 2007.

${ }^{13}$ Edgar Morin, I sette saperi necessari all'educazione del futuro, Raffaello Cortina, Milano, 2001.

${ }^{14}$ Mario Campanino (edited by), Conoscere il suono, la Natura, l'Universo. Comunicare, apprendere e valutare in ambito non formale, CUEN, Napoli 2007.

${ }^{15} \mathrm{http}: / /$ www.etwinning.net/ww/en/pub/xplora/nucleus_home/pencil.htm.

${ }^{16} \mathrm{http} / / / \mathrm{www}$.scienza-under-18.org/.

${ }^{17}$ Scienza under 18. Il sapere scientifico della scuola. Con una ricerca sull'immaginario di scienziati, docenti e studenti, Franco Angeli Milano 2007.

${ }^{18}$ Emma Nardi, Pensare, valutare, ri-pensare. La mediazione culturale nei musei, Franco Angeli, Milano 2007. 